\title{
Development of a height estimation method based on the diameter at breast height of Prosopis alba Grisebach selected populations from a progeny trial in Santiago del Estero, Argentina
}

Frassoni, J. E. and Joseau, M. J.

\begin{abstract}
SUMMARY
The main objective of this work was to develop a height estimation method of Prosopis alba based on the diameter at breast height $(\mathrm{DBH})$ of populations with superior characteristics selected through a progeny trial located in the INTA Experimental Agricultural Station, Province of Santiago del Estero, Argentina. The progeny trial was established in 2008 and consists of 3,671 individuals (202 families). The registered variables were DBH and total height (TH) of 123 individuals, taken at random from the three blocks that make up the trial. Linear regressions were performed to develop the model that best fits height estimation with all the sampled individuals (Al model) and, also using the data of 7 individuals - the three trees of greater diameter, the three of smaller diameter and an individual of intermediate diameter-, called the reduced height estimation model (RHEM model). Al model and RHEM model were satisfactory to estimate height of the trees based on their DBH in the trial of progenies in Santiago del Estero. However, the RHEM model offers an important saving of time and effort, simplifying the field activity.
\end{abstract}

Keywords: white "algarrobo"; allometric variables; height estimation model; linear regressions.

Frassoni, J. E. and Joseau, M. J. (2019). Desarrollo de un método de estimación de altura en función del diámetro a la altura de pecho de poblaciones seleccionadas de Prosopis alba Grisebach establecidas en un ensayo de progenie en Santiago del Estero, Argentina. Agriscientia 36 (2): 89-95

\section{RESUMEN}

El objetivo del trabajo fue desarrollar un método de estimación de la altura de los árboles en función de su diámetro a la altura de pecho (DAP) de poblaciones selectas de Prosopis alba seleccionadas por características superiores, en un 
ensayo de progenie ubicado en la Estación Experimental Agropecuaria de la provincia de Santiago del Estero. El ensayo de progenie fue establecido en el año 2008 y está conformado por 3671 individuos (202 familias). Las variables registradas fueron el DAP y altura total de 123 individuos, tomados al azar de los tres bloques que conforman el ensayo. Se realizaron regresiones lineales para determinar el modelo que mejor ajusta a la determinación de la altura con todos los ejemplares muestreados (modelo TI) y, también utilizando los datos de siete ejemplares -los tres árboles de mayor diámetro, los tres de menor diámetro y un individuo de diámetro intermedio-, denominado modelo de estimación reducido de altura (modelo MERA). Tanto el modelo TI como el MERA fueron satisfactorios para estimar la altura en función del DAP. Sin embargo, el modelo MERA ofrece un importante ahorro de tiempo y esfuerzo en las mediciones.

Palabras clave: algarrobo blanco; variables alométricas; modelo de estimación de altura; regresión lineal.

Frassoni, J. E.: Secretaría de Ciencia y Técnica. Universidad Nacional de Córdoba. Argentina. Cátedra de Silvicultura. Facultad de Ciencias Agropecuarias, Universidad Nacional de Córdoba, Argentina. Joseau, M. J.: Cátedra de Silvicultura. Facultad de Ciencias Agropecuarias, Universidad Nacional de Córdoba, Argentina. Correspondence to: javierfrassoni@agro.unc.edu.ar

\section{INTRODUCTION}

The "algarrobos" are trees of the genus Prosopis, Fabaceae Family, of great importance in the Chaco region, both from the productive and ecological point of view (Verzino and Joseau, 2005), they are considered one of the most commercially valuable resources in the sawnwood market. They are adapted to areas of limiting environmental conditions where other productive systems do not prosper due to their higher demands for soil quality, water availability and appropriate technologies. These attributes, among others, make "algarrobos" one of the most valuable timber resources in the semi-arid region of Argentina (Giménez, Ríos, Moglia and López, 1998). P. alba stands out for its greater potential for the production of quality wood.

It is a widely distributed species, found mainly in the subtropical flat areas of Argentina, Uruguay and Paraguay. It also grows in patches in the semi-arid zones of Bolivia and Perú. In Argentina, $P$. alba is a very abundant species, distributed in the central and northern part of the country, which corresponds to the phytogeographic provinces of Chaco and Espinal (Burkat, 1976). It is found in areas with annual rainfall ranging between 500 and $1200 \mathrm{~mm}$, occurring mainly in the summer period and with absolute extreme temperatures of $48{ }^{\circ} \mathrm{C}$ maximum and $-10{ }^{\circ} \mathrm{C}$ minimum (Verzino and Joseau, 2005). With respect to soil quality, the afforestation of $P$. alba showed tolerance to the presence of salts and high values of sodium in the exchange, with good forest biomass production. Salinity values have been recorded between 4 and $12 \mathrm{dS} / \mathrm{m}$ and $30 \%$ of interchangeable sodium (Pérez, 2014).

Pérez (2014) found that the height mean annual increment (H-MAI) and the diameter mean annual increment (D-MAI) differed according to site quality (SQ I: excellent, SQ III: good and SQ V: poor) in 5-year-old $P$. alba experimental plots. Growth values were higher in SQ I, in higher areas with good fertility, $\left(\mathrm{D}-\mathrm{MAI}=2.8 \mathrm{~cm} \cdot \mathrm{y}^{-1}, \mathrm{H}-\mathrm{MAl}=1.15 \mathrm{~m} \cdot \mathrm{y}^{-1}\right.$ ); medium in SQ III lower topographic areas, with 40 to $50 \%$ of clay (D-MAI $=1.7$ to $2.3 \mathrm{~cm}^{-y^{-1}}$, and $\mathrm{H}-\mathrm{MAI}=0.85 \mathrm{~m}^{-\mathrm{y}^{-1}}$; ; and low in SQ V, soils with 55 to $60 \%$ of clay (D-MAI $=1 \mathrm{~cm} \cdot \mathrm{y}^{-1}$, and $\mathrm{H}-\mathrm{MAl}=0.70$ $\left.\mathrm{m} . \mathrm{y}^{-1}\right)$. As expected, the best growth corresponded to the best site qualities. On the other hand, Verzino and Joseau (2013) found D-MAI of $1.24 \mathrm{~cm} \cdot \mathrm{y}^{-1}$, and $\mathrm{H}-\mathrm{MAl}$ of $1.28 \mathrm{~m} \cdot \mathrm{y}^{-1}$ for the trial in the Yungas; and D-MAI of $1.3 \mathrm{~cm} \cdot \mathrm{y}^{-1}$, and H-MAI of $1.6 \mathrm{~m}^{-1} \mathrm{y}^{-1}$ for the Sub-humid Chaco. On the other hand, Kees et al. (2016) described 4 site indices (SI) for P. alba in Chaco province, analyzing the height and age of the populations (SI $5=3.4 \mathrm{~m}$, SI $7=4.7$, SI $9=6.1$, SI $11=7.5$ ).

This emblematic species cannot and should not be ignored. Due to its environmental, social and economic importance it deserves to be studied, conserved, cultivated and industrialized in a sustainable way (Verzino, Joseau and Coirini, 2012). In this context, good forest management planning is essential, which implies reliable projections of growth and production (García, 1994). Currently, 
dendrometric measurements of field characters often become difficult and expensive, so methods that reduce the amount of measurements are necessary. O'Reagan and Arvanitis (1966) argue that the cost of each sample is defined by the size of the sample. Nowadays, due to the onerous sampling costs, mathematical modeling is an essential requirement for an adequate forest management (García, 2013).

In the measurement of dendrometric characters, and specifically in the estimation of heights, Andenmatten and Letourneau (1997) estimated the volume per hectare of Pinus ponderosa (Dougl.) Laws "ponderosa pine", Pseudotsuga menziesii (Mirb.) Franco "Douglas fir" and Pinus radiata (D. Don) "radiata pine" plantations, located in the Andean Patagonian region of Chubut and Río Negro, Argentina, applying the reduced subsample method for height estimation. The method consisted of measuring the height of the three individuals with the largest diameter and three of the smallest diameter. In 2001, the aforementioned authors used this methodology, which they called "the reduced sample method", for adjusting the height$\mathrm{DBH}$ (diameter at breast height) ratio, in plantations of $P$. ponderosa and $P$. menziesii. In this work they noticed that the height estimation error could be reduced by increasing the number of individuals from the suppressed class. Thereafter, in 2013, Andenmatten and Letourneau adjusted a line for height estimation in Pinus elliottii in the Calamuchita Valley, Córdoba, through measurement of the three trees with the largest diameter and the three with the smallest diameter. In later studies, Andermatten ( $E$. Andermatten, personal communication, November $26,2018)$ suggested to include an individual of intermediate diameter for a better adjustment of the height- $\mathrm{DBH}$ function.

In both methods a semi logarithmic heightdiameter function was used for each plot with the equation $y=\alpha+\beta x \log (d)$, where $\log (d)$ is the $\log _{10}$ of the diameter (d); $\alpha$ and $\beta$ are adjusted parameters for each plot at the time of the inventory $(\mathrm{t}$ ), and $\mathrm{y}$ is the estimated height (Andenmatten and Letourneau, 1997, 2001 and 2013).

In 1997, Andenmatten and Letourneau carried out paired comparisons between some individuals (reduced subsamples) and all individuals (complete subsamples) and found that the maximum percentage difference in volume per hectare due to the estimation of heights by the method of reduced subsample was $6.1 \%$ with respect to the method of complete subsamples. It was concluded that height estimation by means of reduced subsample was a safe, unbiased and simple method compared to the traditional ones. They also point out that reducing the number of samples taken decreased the error caused by fatigue, was cheaper and the inventory was carried out in less time. Actually, there is no reduced method for estimating height in Prosopis species by measuring an easily obtainable variable.

The objective of this work was to develop a method for height estimation based on the tree $\mathrm{DBH}$ of $P$. alba selected populations established in a progeny trial located in the Agricultural Experimental Station, in the Santiago del Estero province, Argentina.

\section{MATERIALS AND METHODS}

The starting material used to adjust the study method was an 8-year-old progeny trial located in the province of Santiago del Estero, in the annex field of the Santa María Agricultural Experimental Station (28 $\left.03^{\prime} \mathrm{S}, 64^{\circ} 13^{\prime} \mathrm{W}\right)$. The study site was 174 meters above sea level, had an average annual rainfall of $578 \mathrm{~mm}$, an average annual temperature of $20.7^{\circ} \mathrm{C}$, and an average temperature $\max / \mathrm{min}$ of $35.2^{\circ} \mathrm{C} / 5.1^{\circ} \mathrm{C}$ respectively (Salto, 2010). The soil is an Aridic Haplustoll, with sandy loam texture. Its main limitation is low moisture retention (SAGyP - INTA, 2013).

The trial had 3,671 trees from 202 progenies (families) of $P$. alba from populations coming from the provinces of Santiago del Estero, Chaco, eastern Salta, Formosa and Entre Ríos. The trial corresponds to a completely randomized 3-block design on non-contiguous single tree plots with variable number of repetitions per family and simple perimeter bordure. The planting distance was 4 x $4 \mathrm{~m}$ in the three blocks (625 trees per hectare). Until the moment the measurements were taken, no pruning or thinning work had been carried out in the trial.

Given the large number of individuals present in the trial $(3,671)$, a subsample of 123 individuals belonging to the three blocks was taken at random. These 123 individuals were measured: the DBH was measured in $\mathrm{cm}$ with dendrometic tape and the total height $(\mathrm{TH})$ was measured in $m$ with telescopic rod. All the selected individuals had good forest form and sanitary status.

An old waterway was detected at the north end of block three. The presence of this waterway could suggest differences in gravimetric humidity between blocks, whereby soil samples were collected up to horizon C. The gravimetric humidity was calculated following the methodology of the soil gravimetric humidity protocol GLOBE (2015).

From the total of randomly sampled individuals, 
sixteen geographical origins were determined and it was evaluated whether there were statistic differences between the origins in terms of $\mathrm{DBH}$ and height.

Taking into account the minimum and the maximum diameter value, five diametric classes (DC) were established with intervals of $5.5 \mathrm{~cm}$. The three trees of larger diameter (LD) were selected within the $\mathrm{DC}_{5}$ (trees with diameters greater than $24.51 \mathrm{~cm}$ ), one of intermediate diameter (ID) in the $\mathrm{DC}_{3}$ (trees between 13.51 to $19 \mathrm{~cm}$ in diameter), and the three of smaller diameters (SD) in $\mathrm{DC}_{1}$ (diameters smaller than $8 \mathrm{~cm}$ ). These 7 individuals were defined as material for the model called reduced height estimation model (RHEM). An evaluation of the frequency distribution of the diameter classes per block was also carried out.

Linear regressions were performed to find the best fitting model between height and diameter variables. First, and due to the difference in height observed in the blocks $\left(\mathrm{TH}_{1}=3.96 \mathrm{~m}, \mathrm{TH}_{2}=4.17\right.$ $\mathrm{m}, \mathrm{TH}_{3}=6.40 \mathrm{~m}$ ), trees from blocks 1 and 2 were analyzed separately from trees from block 3 . Second, all sampled individuals were included,123 in total, Al model= all individuals. And third, only seven individuals were analyzed, the three largest diameter individuals in the trial, the three smaller individuals in the trial and one intermediate individual (RHEM model). The Al and RHEM models were constructed following the methodology used by Andenmatten and Letourneau (1997, 2001) for P. menziesii and P. ponderosa, and the one applied by Andenmatten and Letourneau (2013) for $P$. elliottii and $P$. taeda in Calamuchita.

The statistical analysis were carried out using InfoStat statistical program (Di Rienzo et al 2018). Analysis of Variance (ANAVA) was performed with comparisons of Fisher's Least significant Difference (LSD) between mean height and $\mathrm{DBH}$ by origin, diameter classes and, height and $\mathrm{DBH}$ by blocks.

\section{RESULTS AND DISCUSSION}

The ANOVA performed on height and diameter showed no significant differences ( $p>0.05$ ) among the origins, so the whole group of individuals (123) was taken as a single group for the determination of diametric classes (Table 1).

In the distribution of the individuals of each block by the 5 diametric classes, it was found that most of the individuals sampled from block 1 and 2 belonged to $\mathrm{DC}_{1}(80 \%$ in block 1 and $46 \%$ in block 2). In $\mathrm{DC}_{2}$ and $\mathrm{DC}_{3}$, the participation was mostly of individuals belonging to block 2 ( $19 \%$ for $\mathrm{DC}_{2}$ and
$20 \%$ for $\mathrm{DC}_{3}$ ). In the $\mathrm{DC}_{4}$, no individuals of block 1 were found, and the block that presented more individuals of this case was block 3 , with $30 \%$ of their individuals. Finally, in $\mathrm{DC}_{5}$, a higher percentage $(p<0.05)$ of individuals in block $3(27 \%)$ was observed.

Table 1. Diameter at breast height $(\mathrm{DBH})$ of the individuals that define the diameter classes.

\begin{tabular}{|c|c|}
\hline Diameter classes & $\mathrm{DBH}(\mathrm{cm})$ \\
\hline SD & $6.14 \quad \mathrm{a}$ \\
\hline ID & $14.68 \mathrm{~b}$ \\
\hline LD & $23.44 \mathrm{c}$ \\
\hline
\end{tabular}

Means with a common letter are not significantly different $(p>$ 0.05). References: $S D=$ smaller diameter, ID: intermediate diameter, LD = larger diameters.

Regarding the relative frequencies by diametric classes, it is observed that $\mathrm{DC}$, had individuals of the three blocks almost in the same proportion (32\% for block 1,34 \% for block 2 , and $34 \%$ for block 3 ); that $\mathrm{DC}_{2}$ was composed mostly of individuals from block 2 , and that $\mathrm{DC}_{3}, \mathrm{DC}_{4}$ and $\mathrm{DC}_{5}$ possessed individuals mostly belonging to block 3 .

The ANOVA performed on the height and diameter variables showed differences $(p<0.05)$ in blocks 1 and 2, with respect to block 3 (Table 2). However, these differences were not observed in the gravimetric moisture content per block ( $p>0.05)$, possibly because the sampling date was August 15, at the end of the dry season, which extends from April to September (Santiago Educativo, 2016-2017).

Table 2. DBH and height of Prosopis alba, by block.

\begin{tabular}{lcc}
\hline Block & DBH $(\mathrm{cm})$ & TH $(\mathrm{cm})$ \\
\hline 1 & $9.55 \mathrm{a}$ & $3.96 \mathrm{a}$ \\
2 & $11.27 \mathrm{a}$ & $4.17 \mathrm{a}$ \\
3 & $18.44 \mathrm{~b}$ & $6.40 \mathrm{~b}$ \\
\hline Means with a common letter are not significantly different
\end{tabular}
( $>$ > 0.05).

The average growth in diameter and height obtained for block 3 (D-MAI $=2.3 \mathrm{~cm} \cdot \mathrm{y}^{-1}, \mathrm{H}-\mathrm{MAI}=$ $0.8 \mathrm{~m}^{-1} \mathrm{y}^{-1}$ ) were similar to those obtained by Pérez (2014) for good quality sites in Formosa and higher to those found by Verzino and Joseau (2013) for the Yungas and Sub-Humid Chaco; while those obtained for blocks 1 and 2 (block 1: D-MAI $=1.19$ $\mathrm{cm} \cdot \mathrm{y}^{-1}, \mathrm{H}-\mathrm{MAl}=0.49 \mathrm{~m} \cdot \mathrm{y}^{-1}$, and block 2: D-MAI $\left.=1.40 \mathrm{~cm} \cdot \mathrm{y}^{-1}, \mathrm{H}-\mathrm{MAl}=0.52 \mathrm{~m} \cdot \mathrm{y}^{-1}\right)$ were lower than those found by Verzino and Joseau (2013) and similar to those found by Pérez (2014) for bad quality sites in Formosa. The SI established by Kee 
et al. (2016) determine the height growth observed in block 1 and 2 as belonging to SI 5, while block 3 corresponds to SI 9. Based on these results, two different site qualities were identified, one for the blocks 1 and 2, and another for the block 3 .

Thereafter, regressions were performed by unifying the data of blocks 1 and 2 , on the one hand (Figure 1a, $R^{2}=0.81$ ), and block 3 (Figure 1b, $\left.R^{2}=0.78\right)$, on the other, as well as the three blocks together (Figure 1c, $R^{2}=0.83$ ). Although the values of $\mathrm{R}^{2}$ were similar, the $\mathrm{TH}-\mathrm{DBH}$ linear regression, with the data of the three blocks altogether had a better $\mathrm{R}^{2}$ (model of All Individuals- $\mathrm{Al}$ ) than the other two groups separately. Linear regression analysis for the 7 selected trees of the reduced height estimation model (RHEM), had an $\mathrm{R}^{2}=0.86$ (Figure 1d). Bender, Araujo, Perreta and Moglia (2015) found similar results when they analyzed diameter in function of the height using a potential equation $\left(R^{2}=0.92\right)$ for individuals of four populations of different ages tacked all together while, Cisneros, Moglia and Álvarez (2017) uses linear correlations to estimate height based on diameter $\left(R^{2}=0.56\right)$ in three population of $P$. alba.

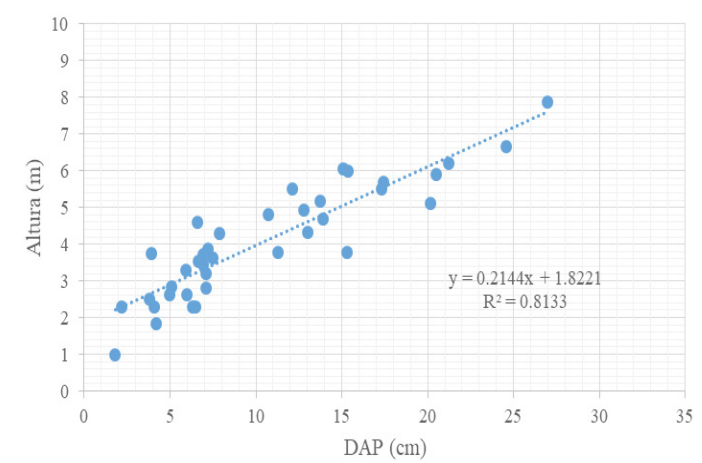

a)

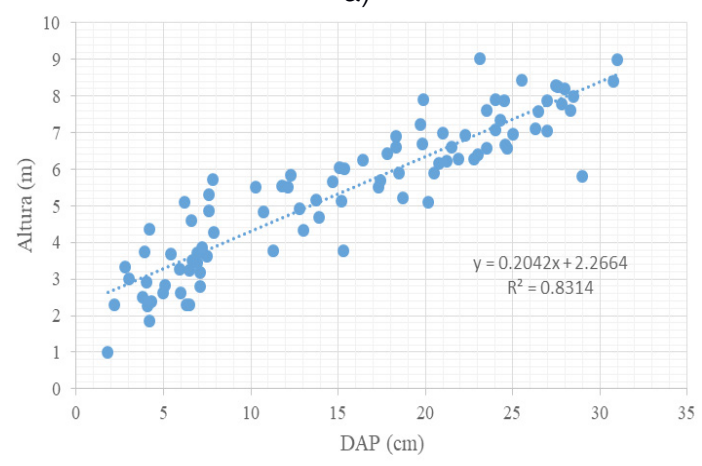

c)

\section{Models}

- Al (All individuals):

$\mathrm{TH}=2.2664+0.2041$ * $\mathrm{DBH}$

- RHEM (Reduced height estimation model):

$\mathrm{TH}=1.8821+0.2009$ * $\mathrm{DBH}$

Where, $\mathrm{TH}$ is the height of the individuals in meters $(\mathrm{m})$ and $\mathrm{DBH}$ is the diameter at breast height $(1.30 \mathrm{~m})$ measured in centimeters $(\mathrm{cm})$.

$\mathrm{Al}$ (Eq. 1) and RHEM models (Eq.2) were good height estimators $(p<0.01)$ in function of the $\mathrm{DBH}$, presenting a mean square error prediction (MSEP) minors than $25 \%(\mathrm{Al}=16 \%$ and RHEM $=21 \%)$, which means that with a significantly smaller number of individuals, the error only increased by $5 \%$. This value is close to the error variations obtained by Andenmatten and Letourneau (1997) with a maximum value of $6.1 \%$.

The best fit in the RHEM model would be due to the fact that it covers a greater breadth of diameters representing the individuals that received greater (block 3) and lower (block 1 and 2) water supply, although both curves overlap. Height adjustment as a function of diameter was linear, as described

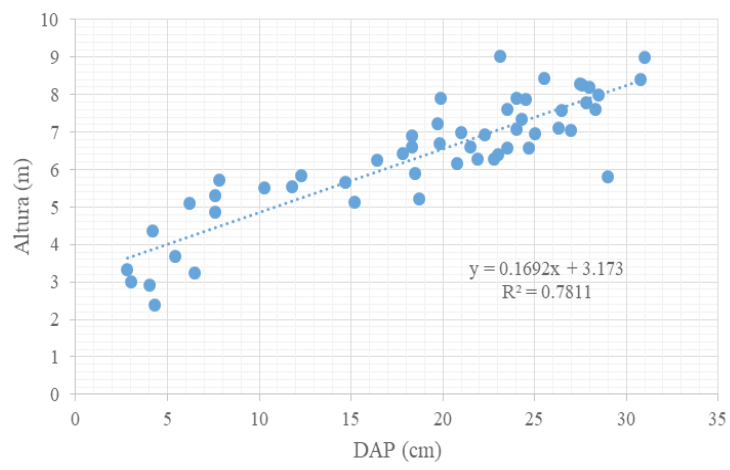

b)

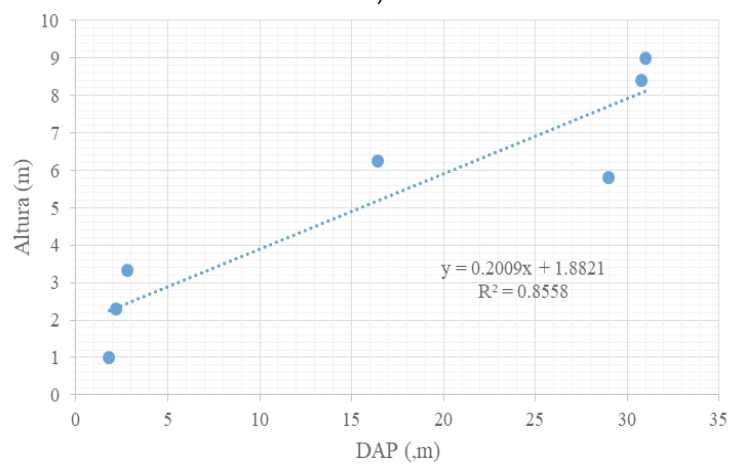

d)

Figure 1. Height in function of DBH: a) block 1 and $2\left(R^{2}=0.81\right)$; b) block $3\left(R^{2}=0.78\right)$; c) Al model $\left(R^{2}=0.83\right)$; and d) RHEM model $\left(R^{2}=0.86\right)$. 
by Andenmatten and Letourneau $(1997,2001)$ for $P$. menziesii and $P$. ponderosa, and by Andenmatten and Letourneau (2013) for P. elliottii and P. taeda in Calamuchita. In the case of $P$. alba it was not necessary to transform the $\mathrm{DBH}$ variable.

The adjusted model is valid at the site where the data were taken, and the methodology must be adjusted for use in another site of different quality and density as described by Andenmatten and Letourneau $(1997,2001)$ for each site under study.

\section{CONCLUSIONS}

The $\mathrm{Al}$ and RHEM models are good height estimators of $P$. alba in a progeny trial in the annex field of Santa María, Santiago del Estero. Both models are safe, and easy to implement; however, the RHEM model offers savings in time and effort, simplifying field activity.

The measurement of the diameter at the breast height of all the individuals that compose the sample and the height measurement of seven $P$. alba individuals (the three trees of greater diameter, the three trees of smaller diameter and an individual of intermediate diameter) from a progeny trial in the annex field of Santa María, Santiago del Estero, Argentina, allows to estimate the total height of the remaining individuals with the use of RHEM model, being a height estimation methodology of easy application.

\section{ACKNOWLEDGEMENTS}

The authors acknowledge the directors of the National Forestry Program-Genetic Improvement of High Value Native Forest Species (Instituto Nacional de Tecnología Agropecuaria -INTA-) and Project PICTO No 1/18608 (Evaluation of the genetic variation of species of the genus Prosopis from Chaco Region, Argentina, for its conservation and improvement) for allowing the use of the trial as a base material for this study. The funds for this work were contributed by the Banco Nacional de Germoplasma de Prosopis and the Secretaría de Ciencia y Tecnología of the Universidad Nacional de Córdoba.

\section{REFERENCES}

Andenmatten, E. and Letourneau, F. (1997). Estimación de alturas para su empleo en tablas de volumen de árbol individual. Quebracho, 6, 27- 34.

Andenmatten, E. and Letourneau, F. (2001). Aportes a la dasometría de plantaciones de pino oregón y pino ponderosa en la región Andino-Patagónica. Comunicación Técnica $N^{\circ}$ 16, Área ForestalSilvicultura, EEA Bariloche, INTA, $30 \mathrm{pp}$

Andenmatten, E. and Letourneau, F. (2013). PILQUITRON 1.1: Simulador para el procesamiento de parcelas forestales. (Comunicación Técnica $n^{\circ} 52$ de INTA Bariloche y Ministerio de Agricultura Ganadería y Pesca). Bariloche.

Bender, A., Araujo, J., Perreta, M. and Moglia J. (2015). Magnitudes dendrométricas de cuatro poblaciones de algarrobo blanco (Prosopis alba Griseb.) de diferentes edades. Revista FAVE - Sección Ciencias Agrarias 14 (1). ISSN 1666-7719. Retrieved from: https:/l ri.conicet.gov.ar/bitstream/handle/11336/69088/ CONICET Digital Nro.c50e45dc-7c65-4624-917bb9029b7d3933_A.pdf?sequence $=2 \&$ is Allowed $=y$

Burkart, A. (1976). A monograph of the genus Prosopis (Leguminosae subfam. Mimosoideae). Journal of the Arnold Arboretum, 57, 219-249.

Cisneros, A. B., Moglia, J. G., and Álvarez J. A. (2017). Relaciones alométricas en árboles individuales de Prosopis alba, en poblaciones naturales de la Región Chaqueña, Argentina. Investigaciones en Facultad de Ingeniería del NOA, 3, 552-559. ISSN 1853-6662.

Di Rienzo, J. A., Casanoves, F., Balzarini, M. G., González, L., Tablada, M. and Robledo, C. W. InfoStat versión 2018. Grupo InfoStat, (software de cómputo) FCA, Universidad Nacional de Córdoba, Argentina. Retrieved from: http://www.infostat.com.ar

García, O. (1994). The state- space approach in growth modelling. Canadian Journal of Forest Research, 24 (9), 1894- 1903.

García, O. (2013). Forest Stands as Dynamical Systems: An Introduction. Modern Applied Science, 7 (5), 3238. Chile. Doi: doi.org/10.5539/mas.v7n5p32

Giménez, A., Ríos, N., Moglia, G., and López, C. (1998). Leño y corteza de Prosopis alba Griseb., algarrobo blanco, Mimosaceae, en relación con algunas magnitudes dendrométricas. BOSQUE, 19 (2), 53- 62. doi: https://doi.org/10.4206/bosque.1998.v19n2-06

GLOBE (2015). Protocolo de humedad gravimétrica del suelo. Retrieved from: http://www.globeargentina. org/guia del maestro web/suelos/protocolos/ prothumedadgravimetrica.pdf.

Kees, S. M., Michela, J. F., Skoko, J. J., Gomez, C. A., Crechi, E. H., and Letourneau, F. J. (August 2016). Índice de Sitio para Prosopis alba en la Provincia de Chaco. Document presented at XVII Jornadas Técnicas Forestales y Ambientales. Posadas, Argentina: INTA. Retrieved from: https://inta.gob.ar/ sites/default/files/indice de sitio para prosopis alba_en_la_provincia_de_chaco.pdf.

O'Reagan, W. G. and Arvanitis, L. G. (1966). Cost- 
effectiveness in forest sampling. Forest Science, 12(4), 406-414.

Pérez, V. R. (2014). Caracterización Edafológica y Silvicultura de Forestaciones de Prosopis alba de la Provincia de Formosa. Producción Forestal, 4 (9), 2832.

SAGyP e INTA (2013). Proyecto PNUD ARG/85/019. (Versión 9.0). Retrieved from: http://www.geointa.inta. gob.ar/2013/05/26/suelos-de-la-republica-argentina/

Salto, S. C. (2010). Variación genética en progenies de polinización abierta de Prosopis alba Griseb. de la región chaqueña. Unpublished master thesis. Universidad Nacional de Rosario, Rosario, Argentina.

Santiago Educativo (2016-2017). Retrieved from: http:// santiagoeducativo.com/clima/.

Verzino, G. and Joseau, M. J. (2005). El Banco Nacional de Germoplasma de Prosopis: conservación de recursos forestales nativos en Argentina- $1^{\text {a }}$ ed. Córdoba. $172 \mathrm{pp}$.

Verzino, G. and Joseau, M. J. (2013). Plantaciones forestales con especies nativas de Argentina en la región central del país. In: Joseau M. J., Conles M. Y. and Verzino G. E. (Eds.), Conservación de recursos forestales nativos de Argentina. El cultivo de plantas leñosas en vivero y a campo. Buenos Aires, Argentina: Editorial Brujas.

Verzino, G., Joseau, M. J. and Coirini, R. (2013). Reunión Nacional del Algarrobo: Actas. (1a ed.). Argentina, Córdoba: Encuentro Grupo Editor 